\title{
Ghana: The Limits of External Democracy Assistance
}

\author{
E. Gyimah-Boadi ${ }^{1}$ and Theo Yakah ${ }^{2}$
}

April 2012

\begin{abstract}
Ghana's experience since the early 1990s indicates that external aid can significantly impact a country's democratic transition. External democracy assistance has been a crucial, positive factor in Ghana's steady evolution into an electoral democracy over the past two decades. Continuing gaps in the quality of Ghana's democracy confirms, however, that even sustained external support and encouragement cannot easily overcome local elite resistance to specific reforms as well as structural and cultural obstacles prevailing in the domestic environment, at least in the short and medium terms.
\end{abstract}

Keywords: Ghana, electoral democracy, foreign aid

JEL classification: D72, F35, N47

Copyright (C) UNU-WIDER 2012

${ }^{1}$ Ghana Center for Democratic Development (CDD-Ghana), University of Ghana; email: gyimah@cddghana.org; ${ }^{2}$ CDD-Ghana, University of Virginia (USA), email: theoyakah@gmail.com

This working paper has been prepared within the UNU-WIDER project 'Foreign Aid and Democracy in Africa' directed by Danielle Resnick, which is a component of the larger UNU-WIDER programme 'Foreign Aid: Research and Communication (ReCom)'.

UNU-WIDER gratefully acknowledges specific programme contributions from the governments of Denmark (Ministry of Foreign Affairs, Danida) and Sweden (Swedish International Development Cooperation Agency, Sida) for the Research and Communication (ReCom) programme. UNU-WIDER also acknowledges core financial support to UNU-WIDER's work programme from the governments of Finland (Ministry of Foreign Affairs), the United Kingdom (Department for International Development), and the governments of Denmark and Sweden. 
The World Institute for Development Economics Research (WIDER) was established by the United Nations University (UNU) as its first research and training centre and started work in Helsinki, Finland in 1985. The Institute undertakes applied research and policy analysis on structural changes affecting the developing and transitional economies, provides a forum for the advocacy of policies leading to robust, equitable and environmentally sustainable growth, and promotes capacity strengthening and training in the field of economic and social policy making. Work is carried out by staff researchers and visiting scholars in Helsinki and through networks of collaborating scholars and institutions around the world.

www.wider.unu.edu publications@wider.unu.edu

UNU World Institute for Development Economics Research (UNU-WIDER)

Katajanokanlaituri 6 B, 00160 Helsinki, Finland

Typescript prepared by Liisa Roponen at UNU-WIDER

The views expressed in this publication are those of the author(s). Publication does not imply endorsement by the Institute or the United Nations University, nor by the programme/project sponsors, of any of the views expressed. 


\section{Introduction}

Multi-party democratic rule has flourished in Ghana's Fourth Republic, despite its fairly unpromising beginnings. Major challenges and deficits have persisted, but the country has made tremendous gains in democratic development since 1992. While other newly democratizing African states have suffered reversals or stagnated since Africa joined democracy's 'third wave', Ghana's democracy has gained in strength. This study analyses the role that external donor support has played in the democratic governance achievements of Ghana in its Fourth Republic, with particular emphasis on the competitive multi-party politics, elections, oversight of the executive, parliament and political parties. It contends that external aid in general, particularly democracy assistance, has been tremendously helpful in keeping Ghanaian democracy on track and attaining the status of an electoral democracy (Freedom House 2011), but has had a mixed record at best in helping the country to consolidate its democracy (i.e., the institutionalization of democratic norms and best practices). It also speculates that more recent developments in Ghana, including the discovery of oil and gas resources, the emergence of China and other non-traditional development partners, and the increasing resort to budget support by Western donors, will increase the influence of external factors on Ghana's democratic development, but not necessarily in a positive way.

\subsection{Democratic progress and challenges in the Fourth Republic}

Ghana's re-democratization project began in the early 1990s on a somewhat inauspicious note. The transition initiated by the eleven-year-old quasi-military Provisional National Defence Council (PNDC) administration led by Flight Lieutenant Jerry Rawlings largely aimed at pre-empting Western donor pressure and other global and African pro-democracy developments of the same period. The PNDC rebranded itself as a political party, known as the National Democratic Congress (NDC), with Rawlings as its standard-bearer, to contest multi-party elections against an assortment of opposition parties within the framework of a liberal democratic constitution (1992 Constitution). 1 The administration managed the transition to secure favourable outcomes for itself. For instance, it packed the transition bodies with pro-Rawlings/PNDC partisans, and kept the transition agenda and timetable closely guarded. Moreover, the eleven-year-old ban on political party activities was lifted rather late in the process, forcing the opposition to operate largely in a clandestine manner until close to the election date, and opponents of the regime who were in jail or exile were only given conditional and fettered amnesty. In addition, a residual 'culture of silence' prevailed for most of the transition period, with the government retaining its near monopoly over the print and electronic media. Deeply outraged by the results of the presidential polls held in November 1992,2 the main opposition parties boycotted the ensuing parliamentary polls in December. 3

1 A new fairly liberal democratic constitution (the 1992 Constitution) made provisions for a president and a parliament elected through universal adult suffrage, with a two-term limit on presidential tenure, the protection of a wide array of human rights, and an independent judiciary, among others. Article 55 of the Constitution (and later the Political Parties Act 547) provided the basic framework for a multiplicity of political parties to flourish in Ghana's Fourth Republic.

2 See NPP's Stolen Verdict (1992), backed by the Carter Center and other international observers. The opposition's claims rested, among other factors, on the PNDC's refusal to be neutral in the election, the packing of the transition bodies with pro-Rawlings/PNDC partisans, the opacity of the transition timetable, 
The opposition parties and other critics dismissed the entire process of return to democratic rule in the early 1990s as 'transition without change'. This was because some provisions of the 1992 Constitution appeared as if they had been tailored to enable the departing military rulers to retain some of the autocratic powers they had wielded under military rule, including 'permanent' transitional provisions, thereby giving blanket immunity to Rawlings and the military governments he previously led (i.e. Armed Forces Revolutionary Council and PNDC). As the elected president of Ghana, Rawlings also retained many of the ministers from his previous government in the new NDC administration. Additionally, the de facto oneparty parliament (in which the ruling NDC and alliance parties controlled 198 of the 200 seats), whose Speaker had been deputy chairman of PNDC, largely rubber-stamped executive branch initiatives.

Nevertheless, Ghana's democracy has steadily improved since the inauguration of the new Republic on 7 January 1993. Successive multi-party elections, especially since the second transition polls in 1996, have been highly competitive and their outcomes generally credible, with the 2000 and 2008 elections resulting in electoral turnovers that make Ghana somewhat unique among African democracies. The fact that John Evans Atta Mills narrowly won the run-off presidential election against the candidate of the incumbent NPP party in 2008 with less than half a percentage point, and that power was actually handed over on schedule in January 2009, is a measure of the excellent progress the country has made in achieving election transparency.

Additionally, a highly vibrant media and civil society have emerged and civil-military relations have been substantially democratized. For instance, the 64th infantry battalion, previously controlled by Rawlings, has been integrated into the regular military, and the military budget also has been brought under parliamentary scrutiny. Ghana's ombudsman, the Commission on Human Rights and Administrative Justice, and other official human rights bodies, as well as media and civil society bodies, are able to monitor the military and security sector (Gyimah-Boadi 2009a, 2010a; Whitfield 2009). And the nation has remained largely united and politically stable, despite significant religious and ethno-regional diversity.

Moreover, governments elected in the Fourth Republic generally have managed the economy prudently, leading to relative macroeconomic stability and a decline in inflation from around 74 per cent in 1993 to 8.7 per cent in January 2012 (MOFEP 2012; Pereira 2000). Poverty rates, for example, have also declined from a high of 51.7 per cent in 1992 to around 28.5 per cent in 2006.4 Ghana has also made significant strides in providing social services, including the introduction of a national health insurance scheme, a capitation grant for pupils in basic schools, and a pilot school feeding programme. Substantial investments in infrastructural development have resulted in major road construction projects and the commissioning of a hydro-electricity project in the northern region. These achievements in democratic governance are confirmed in recent democracy and governance assessments of Ghana, such

the continued ban on party political activities until very late in the transition process, the conditional nature of the amnesty granted to opposition politicians prior to the elections, restrictions on the ability of the opposition to access funds and media, and a government monopoly over the state media.

3 Two independents, Hawa Yakubu and John Achiluwor, completed the configuration.

4 The World Bank, Ghana Economic Indicators, at - http://data.worldbank.org/country/ghana 
as the New Partnership for African Development's African Peer Review Mechanism, 5 World Bank Institute, 6 and the Mo Ibrahim Index of African Governance. 7

To be sure, significant challenges and deficits remain, especially in moving from electoral democracy to consolidation (O’Donnell 1996). Governmental accountability and transparency are severely inadequate. To date, the salaries and other conditions of service attached to the position of the president, ministers of state, parliamentarians and other key state functionaries are shrouded in secrecy. Institutional checks-and-balances remain weak, as power is legally and constitutionally over-concentrated in the executive branch, especially the presidency and governing political party. The rule of law also remains poorly entrenched, and access to justice is inadequate, especially for ordinary citizens in the rural and peri-urban areas, which partly explains the high incidence of mob justice and vigilantism.

Moreover, women and disabled persons suffer considerable exclusion, and sexual minorities continue to face discrimination. Inequality across regions and between the sexes remains high; levels of deep poverty and high unemployment persist, fuelling class, ethnic and regional resentments that could be exploited for political gain.

Administrative, fiscal and political decentralization remains weak as the executive branch uses its grip on power and control of patronage to stall the constitutionally-mandated programme of decentralizing administrative power to the district assemblies and their substructures. 8 Thus, local government continues to be undermined and the level of responsiveness and accountability of its agencies and its officials to the citizenry remains extremely weak. Furthermore, the effectiveness of Ghana's public bureaucracy is undermined by politicization and persistent 'clientelization of the democratic politics'. Chief executives, chairs and other governing board members of the country, including public utilities, are typically appointed by presidential fiat, largely on the basis of partisan political criteria rather than merit.

Extreme partisanship and political polarization have also persisted, especially between the NPP and NDC, as members of both parties see the control of the state as the most lucrative avenue for group and individual wealth and influence. In addition, voting patterns indicate continuing ethnic and regional chauvinism: an overwhelming percentage of votes cast in presidential and parliamentary polls in the Volta Region consistently go to the NDC and those cast in the Ashanti Region go to the NPP.9

5 African Peer Review Mechanism, Country Review Report of the Republic of Ghana, June 2005 http://www.afdb.org/fileadmin/uploads/afdb/Documents/Project-and-Operations/00798283-EN-APRMGHANA-REVIEW-REPORT-JUNE-2005.PDF. Retrieved on 12 March 2012.

6 World Bank, Governance Reports: Country Data Report for Ghana, 1996-2010 http://info.worldbank.org/governance/wgi/pdf/c82.pdf. Retrieved on 12 March 2004.

7 Mo Ibrahim Foundation, Ghana ranks 7th out of 53 countries in latest assessment of African governance, 9 October 2011. http://www.moibrahimfoundation.org/en/pressrelease/media-centre/press-releases/ghanaranks-7th-out-of-53-countries-in-latest-assessment-of-african-governance.html. Retrieved on 12 March 2012.

8 Refer to Articles 231-256 for the decentralization provisions in the 1992 Constitution of Ghana.

9 NDC captured parliamentary seats in 21 of the 22 constituencies in the Volta Region, while the NPP secured 36 of the 39 seats in the Ashanti Region in the 2008 parliamentary polls. The presidential results show similar trends of ethnic-bloc voting in these regions. 
Deficits in civic culture prevail. Popular understanding of the democratic political process is generally underdeveloped. Passive rather than active forms of political and civic participation remain dominant, reflecting, in part, insufficient civic education. According to data from the 2008 Afrobarometer survey, only a minority of people engage in active forms of secular community and civic activities: 43 per cent report never having attended a community meeting; 46 per cent have never come together with others to raise an issue; and fewer than one in ten Ghanaians have ever attended a demonstration or protest march. Popular attitudes also betray an extremely weak sense of civic responsibility and, by implication, weak demand for political accountability. For example, the same survey found that only a quarter of the population believe that voters have a responsibility to ensure that MPs do their jobs and only 28 per cent think it is the responsibility of citizens to ensure that the president performs his duties.

In addition to the above, there are significant new challenges to democratic governance under the Mills-NDC government. Despite the thin margin of its victory in both the presidential and parliamentary elections, the Mills-NDC administration favours a highly partisan approach to politics. Like the Kufuor-NPP administration, it has continued to evolve as a 'party-ingovernment system' in which presidential appointments to state/parastatal boards/councils and trusts, ranging from HIV/AIDS control and disaster management, are ruled by party affiliation. Ruling party activists have been allowed to forcibly confiscate public facilities, such as toilets, taxi ranks and tollbooths, and take control of local councils, as some form of political spoils.

Finally, a significant oil and gas sector, roughly estimated to produce 120,000 barrels per day along with a daily output of 120 cubic feet of gas generating about US\$1 billion in government revenue year in the next twenty years has emerged since 2007.10 But there is hardly any evidence that Ghana's democratic institutions, as well as its legal and constitutional arrangements, can credibly guarantee transparent, accountable and responsible use of such resources. Indeed, production and export activities started in 2010 ahead of the development of the legal framework and institutions to regulate the sector, and a provision in the new oil sector regulatory and revenue management legislation permit the state to use approximately 30 per cent of revenue as collateral for public borrowing loans, which represents a dangerous loophole for forward spending. 11

\section{Overview of donor activities in Ghana}

External factors played an important catalytic role, albeit indirectly, in Ghana's retreat from quasi-military to multi-party democratic rule in the late 1980s and early 1990s. 12 They

10 A consortium of companies announced the discovery of commercial quantities of oil off the western coast of Ghana in June and September 2007. Located some 60 kilometres offshore in the Gulf of Guinea, the Jubilee field has estimated reserves of 600 million barrels of oil, with an upside potential of 1.8 billion barrels. See also the 2009 ISODEC-OXFAM America Report by Ian Gary.

11 For a critique of the legal regime for the management of the sector and revenues derived from it, see RamosMrosovsky (2012), 'Ghana’s Oil Boom: A Readiness Report Card’ issued by The Civil Society Platform on Oil and Gas (April 2011); RWI (2011: 1-12); Gary (2009).

12 They include the contagion effect of global developments in the late 1980s, notably the collapse of communism, the end of the Cold War and demise of the PNDC regime's 'communist bloc backers', notably, 
bolstered domestic opposition pressure for a return to democratic rule, which the PNDC had persistently rebuffed in the past. External involvement, including foreign aid, became even more robust after the inauguration of the Fourth Republic on 7 January 1993.13

Indeed, foreign aid to Ghana has increased substantially since the successful economic reforms of the 1980s and especially after the return to constitutional rule in 1992. Ghana receives aid from both traditional and non-traditional donors. The former currently comprises 23 multilateral and 24 bilateral donors (MOFEP 2010). The multilateral donors include the World Bank, African Development Bank, European Union, Nordic Development Fund, Arab Bank for Economic Development in Africa, European Investment Bank, OPEC Fund for International Development, Global Fund to Fight AIDS, Tuberculosis, and Malaria (Global Fund), Global Alliance for Vaccines and Immunization, and 12 organs/agencies of the United Nations. 14 The World Bank is the largest multilateral donor, providing over 45 per cent of the multilateral average (Quartey et al. 2010). The bilateral donors are made up of traditional donors like Australia, Belgium, Canada, Denmark, Finland, France, Germany, Italy, Japan, Netherlands, Norway, Spain, Sweden, Switzerland, UK, and USA (MOFEP 2010). The nontraditional donors, who are increasingly expanding their presence, include Brazil, China, India, Russia, the Saudi Fund, and the Abu Dhabi Fund (ibid).

Foreign assistance to Ghana comes in four categories: debt relief from the Multilateral Debt Relief Initiative (MDRI) and the Highly Indebted Poor Countries (HIPC) Initiative; project aid (loans and grants for supporting specific projects and activities); general sector and budget support; and balance-of-payments support from the International Monetary Fund (IMF), which stopped after 2006 but was reinitiated from 2009 to 2012. Project aid, estimated at 57.4 per cent in 2009, constitutes the bulk of the Overseas Development Assistance (ODA) portfolio in Ghana (GoG 2010). General Budget Support has increased from 27.7 per cent in 2003 to 32.6 per cent in 2010 (Quartey et al. 2010). Budget support has been increasing because of the introduction of the multi-donor budget support (MDBS) mechanism in 2003, which allows donors to contribute to a common pool to support the national budget. The MDBS' main goal is to harmonize the policies and procedures of development partners in order to minimize transaction costs for the government. The MDBS constitutes about 30 per cent of donor inflows to Ghana and has made aid commitments more predictable (Quartey et al. 2010).

In nominal terms, aid inflow increased from approximately US\$1 billion to US\$1.9 billion between 2003 and 2010 (Table 1). This increase was driven by growth in all four categories of aid. Aid as a percentage of GDP increased from 13.2 per cent in 2003 to 14.6 per cent in 2009 and dropped slightly to 12.8 in 2010 (Quartey et al. 2010).

Romania, Bulgaria, East Germany; the contagion effect of global and African pro-democracy movements and developments, including the release of Mandela after 27 years in prison and the unravelling of the apartheid regime in South Africa; the emergence of 'pro-democracy movements' in Africa (prominently featuring regional neighbour, Benin); pressure from Ghana's multi-lateral and bilateral development partners who had begun to attach political 'conditionalities' to loans and grants; and post-Cold War international isolation of non-democratic governments.

13 See Gyimah-Boadi (1997).

14 FAO, IFAD, ILO, IOM, UNAIDS, UNESCO, UNFPA, UNICEF, UNIDO, UNDP, WFP, and WHO. 
Table 1

Ghana overseas development assistance in US\$ millions, 2003-10

\begin{tabular}{|c|c|c|c|c|c|c|c|c|}
\hline & 2003 & 2004 & 2005 & 2006 & 2007 & 2008 & 2009 & 2010 \\
\hline Total & 1003.0 & 1130.1 & 1205.8 & 1471.8 & 1656.5 & 1649.6 & 2102.5 & 1896.8 \\
\hline IMF* & 76.6 & 38.7 & 38.2 & 116.6 & 0.0 & 0.0 & 200.0 & 200.0 \\
\hline Debt relief grants & 154.2 & 174.1 & 196.9 & 307.3 & 342.7 & 229.5 & 289.6 & 235.8 \\
\hline HIPC & 154.2 & 174.1 & 196.9 & 209.8 & 246.1 & 158.4 & 191.9 & 168.8 \\
\hline MDRI & 0 & 0 & 0 & 97.5 & 96.6 & 71.1 & 97.7 & 67 \\
\hline Budget support & 277.9 & 316.7 & 313.2 & 349.3 & 386.7 & 473.1 & 700.4 & 619.2 \\
\hline MDBS & 277.9 & 309 & 281.9 & 312.2 & 316.6 & 368.1 & 525.2 & 451.2 \\
\hline SBS & 0 & 7.7 & 31.3 & 37.2 & 70.1 & 104.9 & 175.2 & 167.7 \\
\hline SWAp & 0 & 0 & 0 & 0 & 12.1 & 15.2 & 86.9 & 81.2 \\
\hline Earmarked & 0 & 7.7 & 31.3 & 37.2 & 58.0 & 89.8 & 88.2 & 86.5 \\
\hline Project aid & 494.4 & 600.6 & 657.5 & 698.6 & 927.0 & 947.0 & 912.5 & 841.8 \\
\hline GDP & 7621 & 8853 & 10726 & 12729 & 14984 & 16085 & 14385 & 14870 \\
\hline Total ODA (\% of GDP) & 13.2 & 12.8 & 11.2 & 11.6 & 11.1 & 10.3 & 14.6 & 12.8 \\
\hline
\end{tabular}

Source: Data from Quartey et al. (2010). * Balance of Payments Support.

In August 2006, Ghana signed a five-year US\$547 million compact with the Millennium Challenge Corporation (MCC). Ghana qualified for the MCC compact on the strength of both its economic and governance performance during the Fourth Republic. The Ghana compact is directed at reducing poverty by improving rural agriculture, transportation, and the provision of services for the rural poor. The programme currently operates in areas where poverty rates are generally above 40 per cent, including 23 districts in the northern region, the Central Afram Basin, and the southern horticultural belt in southeastern Ghana. So far, the MCC money has been used to support the training of farmers in commercial agriculture, irrigation development, improvements to the land tenure system, construction of road networks, and the provision of water and sanitation facilities for rural communities.

Aid figures from non-traditional donors like China are relatively small compared to Western donors and are typically directed at funding infrastructure projects. In 2002, for example, the Chinese government provided Ghana with an interest-free loan of US\$30 million for the construction of the 16.9 kilometre Ofankor-Nsawam section of the Accra-Kumasi road. In 2006, they also gave Ghana a concessional loan of 250 million Yuan (US\$30 million) to finance the first phase of the National Communications Backbone Network Project, which aims to connect all ten regional capitals to the internet. Another US\$30 million loan was granted in 2007 to develop ICT facilities for Ghana's security agencies. The Chinese government also provided aid money for the construction of the Bui Hydro-Electric Power Dam, consisting of US\$270 million in concessional loans and a US\$332 million buyer credit facility. 15 The project is to be executed by the Sino-Hydro Corporation. Chinese aid has not been limited to infrastructure; in 2007, for instance, the country wrote off US\$25 million of Ghana’s debt.

15 The credit facility is from the China Eximbank. 


\section{External aid and competitive and credible multi-party elections in Ghana}

The progressive improvements in competitiveness, peacefulness and credibility in multi-party elections in Ghana's Fourth Republic provides a good illustration of the strategic role external aid has played in the country's overall democratic development. Ghana's remarkable progress in moving from the flawed 1992 elections to two peaceful electoral turnovers in 2000 and 2008 can be credited, in no small measure, to the support of the donor community towards building credible electoral systems and strong political parties.

For the 1996 polls, for example, external donors invested considerable effort in redressing the flaws in the country's electoral processes that were responsible for the nearly abortive transition to democracy. The US government, through USAID, committed US $\$ 9$ million, which brought in the International Foundation for Electoral Systems to provide on-site technical support to Ghana's Electoral Commission (EC). Some of the funds also went towards the purchase of election materials, equipment and technical assistance for voter registration (in view of the widespread perception that the existing register was over-bloated) and payment of sundry election administration expenses. The Danish government provided US\$3 million to replace opaque ballot boxes from previous elections with transparent ones, to pay for the training of voter registration, exhibition and polling staff, and to conduct voter education. The UK gave US\$0.8 million for voter registration forms and equipment for scanning voter registration forms.

Another important initiative funded by donors was the Inter-Party Advisory Committee (IPAC). Formed in March 1994, IPAC, whose meetings were presided over by the EC, brought together representatives of the ruling party and opposition parties (and occasionally donors) to discuss election-related problems and arrive at consensus on how to resolve them (Quartey et al. 2010). Through the IPAC platform, the opposition parties successfully negotiated for the introduction of significant transparency measures, including polling station vote counting, the use of transparent ballot boxes, and the presence of party agents at polling stations. Agreements reached at the IPAC enabled the EC to introduce reforms that raised general confidence in the electoral system. For instance, parties and candidates were given the right to have their agents observe both the voter registration and polling processes, and parties could scrutinize and seek corrections to the provisional voters' register. The implementation of these reforms significantly reduced voter fraud and further improved the relative integrity of subsequent polls. They also proved crucial in restoring the confidence of the main opposition parties in the electoral process and encouraging them to participate in the second transition elections. The reforms helped to render the 1996 polls more competitive and their outcomes more credible. Above all, they paved the way for further progress on the Ghanaian democratic project.

Continued support for subsequent elections from a number of additional external donors, including the United Nations Development Programme (UNDP), the Canadian International Development Agency (CIDA), the European Union (EU), and the Dutch government-funded Netherlands Institute for Multiparty Democracy (IMD), contributed to improvements in Ghana's election management and levelled the electoral playing field. Such support includes funding for the introduction and progressive expansion of photo identification cards in the polls, which began in 1996 and has helped to reduce impersonation and secure improvements in election integrity. European Union funding of approximately €2 million in 2004 and 2008, respectively, enabled the Electoral Commission to procure and print the ballot papers used in the elections. The willingness of external donors to provide funding and technical assistance 
to Ghanaian elections after 1992 has substantially reduced opportunities for incumbent administrations to manipulate the process by deliberately starving the EC of funds.

In addition, external donors have almost nearly exclusively bankrolled the numerous projects that Ghana's domestic civil society and media have initiated to promote election transparency and credibility since the mid-1990s. A US government-sponsored project in 1996 enabled local civic groups, notably, the Institute of Economic Affairs (IEA) and Ghana Alert, to embark on Ghana's first non-partisan domestic election observation project. The IEA effort, undertaken in collaboration with the US-based National Democratic Institute for International Affairs (NDI), for instance, brought together over twenty civic bodies (the Network for Domestic Election Observers, NEDEO), which recruited 4,100 volunteers to watch election activities throughout the country. Generous external donor funding has been crucial to the increasing ability of Ghana's domestic civil society and media to significantly scale up and professionalize their involvement in successive election support projects. Similarly, in 2008, German Embassy funding enabled the Ghana Center for Democratic Development/Coalition of Domestic Elections Observers (CDD-Ghana/CODEO) to systematically monitor election violence and undertake conflict prevention in northern Ghana and other conflict-prone areas. USAID funding and NDI's technical support enabled the group to field over 4,000 observers nationally and to conduct a parallel vote count, which was a novelty in Ghanaian polls.

Similarly, the Friedrich Ebert Foundation and USAID-funded civil society and media projects that helped to assuage one of the crucial concerns of the opposition parties and candidates in the 2000 polls: 'unfair treatment' and 'inadequate coverage' in the state-owned media, contrary to the provisions of the Constitution (see Quartey et al. 2010). Under this project, CDD-Ghana and the Ghana Journalists' Association (GJA) systematically monitored media coverage of the campaigns of the various parties, widely publicizing the findings and using that material for educating media practitioners about their democratic and professional obligation to promote balanced political reporting and equity in coverage of all parties and candidates (see CDD 2001). 16 The UK's Westminster Foundation for Democracy funded a CDD-Ghana programme in 2004 that systematically monitored abuse of state power and resources by the incumbent government/ruling party for electoral advantage. UNDP, DFID and other donors have bankrolled the well-received peace campaigns and conflict mediation activities undertaken by Ghanaian traditional and religious leaders, artistic and entertainment personalities, media, secular and religious civil society bodies since 2000.

The EU has been a key sponsor of extensive voter education programmes undertaken by state bodies such as the National Commission for Civic Education and the EC, and non-state bodies such as the Institute for Democratic Governance (IDEG), the Institute for Policy Analysis (IPA), IEA and others. A consortium of donors funded the well-received forums organized by the IEA for presidential candidates to sell themselves and their ideas to the public in 2004 and 2008. The same agents have financed the campaigns for peace and decorous conduct in elections undertaken by the GJA, Christian and Muslim Councils (working under the Forum for Religious Bodies), which have fostered largely peaceful and credible elections. Importantly, the period covered by these civil society election support projects has progressively increased from weeks to months, thus rendering relevance to both the period before and after the actual polling day.

16 The Friedrich Ebert Foundation and the Center for Democracy and Development in particular, in collaboration with the Ghana Journalists' Association, sponsored a series of workshops and seminars for media practitioners during 1999. See, for example, CDD (1999). 
Nevertheless, election administration remains weakly institutionalized in Ghana. Among other deficiencies, the integrity of the voters' register remains questionable. Election administration relies largely on large numbers of temporary personnel of questionable professional calibre and integrity, and the overall credibility of Ghana's EC largely depends on the personal credibility and record of the incumbent election commissioner who retires after 2012. In addition, Ghanaian elections have, in fact, been fraught with extreme tension, including intimidation, organized thuggery, and sporadic flare-ups of violence, despite overall success (Gyimah-Boadi 2009a). Furthermore Ghana's two main political parties, in the firm belief that it is possible to achieve electoral victory by outdoing the other in intimidation and rigging, have shown little interest so far in correcting some of these lingering barriers towards further improving the credibility and peacefulness of Ghanaian elections. Notwithstanding these continuing challenges, however, there has been significant change in the transparency, fairness, and credibility of Ghanaian elections since the disputed first transition polls.

\section{External donors and the effectiveness of Ghana's parliament}

Parliament has emerged as a key institution of democratic governance in the Fourth Republic, although it remains subordinate to the Executive Branch. The Ghanaian parliament has increasingly become active in the performance of its constitutional and political functions. Its involvement has somewhat increased with respect to the review and approval of legislative initiatives, international loans and agreements submitted to it by the executive branch. On several occasions, the House has referred back to the executive branch draft legislations and international agreements it found defective. This was true for the National Reconciliation Commission Act 2002 (Act 611), the Labour Act 2003 (Act 651), the Public Procurement Act 2003 (Act 663) and the Civil Aviation Act 2004 (Act 678) (Tsekpo and Hudson 2009). Parliament has also tried to exercise some degree of oversight over the government, as reflected in the work of the select committee on appointments, whose negative recommendations on some nominees for ministerial appointments have caused the president to change his mind (ibid). The Public Accounts Committee (PAC) may best illustrate the success of the Fourth Republic's Parliament. Chaired by a minority MP, as per the Constitution, the PAC's review of audit reports on government agencies and public hearings have attracted widespread public interest. It has gained relevance in the promotion of public accountability in Ghana by reviewing the Auditor-General's annual reports, reprimanding institutions and officials found to have abused or misused public funds, demanding the retrieval of such funds and, occasionally, recommending prosecution. Communication between the Public Affairs Department of Parliament and the media, as well as the general public, has also improved considerably over time.

Nonetheless, the performance of Ghana's legislature remains lacking in many respects. Parliamentary oversight of the executive is largely perfunctory. It has approved loan proposals and international agreements backed by extremely inadequate or/and, at times, incorrect information. Budgets and spending proposals submitted by the executive are typically poorly scrutinized and often approved on a strictly partisan basis. In addition, parliament, especially its committee activities, is chronically under-resourced, which is reflected in the lack of office space and weak capacity of the parliamentary bureaucracy, including research and drafting services. As a result, the legislature has consistently lacked the capacity to perform some of its most basic functions. 
The parliament of the Fourth Republic is, at least in part, a victim of a negative inheritance. While the executive and judicial branches of government have continued to exist in some form throughout the periods of political upheaval, parliament has been proscribed under all military administrations. As a result, the current parliament inherited a very weak institution, with very shallow institutional memory and dubious parliamentary culture. Moreover, key provisions of the constitution of the Fourth Republic, particularly Articles 78 and 108, aggravate the problems of Ghana's legislature. Article 78 stipulates that a majority of ministers should be selected from among MPs. 17 The common interpretation and application of this provision severely limits the independence of parliament. Thus, parliament has typically had at least 40 of its members concurrently serving as part of the executive, promoting the president's agenda in the legislature at the latter's expense. A very effective party-whip system ensures that the executive branch largely succeeds in getting most of its initiatives and proposals approved by the House. Furthermore, the demands of ministerial responsibility, coupled with the higher levels of substantial power, prestige, perks and opportunities for patronage attached to a ministerial appointment, mean that MPs appointed to serve as ministers invariably allow their parliamentary duties to suffer neglect.

Article 108 of the Constitution is arguably an even greater impediment to parliamentary independence. As currently interpreted and applied, this provision bars parliament from proposing on its own initiative any bill that imposes a financial burden on the state, which effectively leaves only the executive to introduce bills that would impose a charge on the national treasury. This significantly diminishes parliament's ability to seek legislative solutions to Ghana's numerous public policy challenges. Article 108 also leaves parliament without the power to determine or influence its own institutional budget. In fact, as per the conventional reading of Article 108, parliament can only reduce but not increase the funds allocated to a particular line item in the executive's budget proposals.

The extremely high turnover of MPs every four years presents yet another challenge. It undermines the development of the legislature's institutional memory. It also deprives it of some experienced and able legislators in favour of inexperienced ones along with the benefit of earlier capacity development efforts.

In addition, some conventions and practices of Ghana's legislature as well as habits of MPs undermine the autonomy of the institution. The speaker of parliament, who wields enormous powers over the rules of parliamentary debates, is picked by the president and only later approved by a simple majority in the House (under a convention not backed by law). Consequently, the speakers typically ensure that the will of the president or the preferences of the ruling party prevail, which further undermines the political and legal clout of the legislative body.

External donor assistance has been targeted at mitigating the weaknesses of the parliament of Ghana's Fourth Republic and strengthening its overall capacity. Beginning in the early 1990s, USAID's 'international visitors' programme offered selected members of parliament the opportunity to tour and learn about the workings of the US Congress and other key institutions of the American government. The Friedrich Naumann Stiftung organized a similar one in 2004 for MPs to tour the German parliament and to learn about their decentralization

17 Article 78 clause (1): Ministers of State shall be appointed by the President with the prior approval of parliament from among members of parliament or persons qualified to be elected as members of parliament, except that the majority of ministers of state shall be appointed from among members of parliament. 
system. Study visits by parliament members and staff of the parliamentary bureaucracy have been a regular feature of support from Ghana's development partners, especially the western democracies. In the judgment of Doe Adjaho, a veteran parliamentarian and currently a deputy speaker of parliament, the MPs who participated in the training programme have become effective legislators in the Fourth Republic.18

Recognizing Ghana's history of overly powerful executives, donor support has justifiably focused on improving the capacity of the parliament. The United States' NDI was also a key player in the effort to build and strengthen the capacity of parliament. Between June 1997 and October 2000, NDI organized a series of training workshops aimed at building parliamentary capacity to draft and review legislation independent of the executive branch, strengthen the work of parliamentary committees, and increase the capacity of Ghanaian NGOs to use available avenues to influence the legislative process. Between 2000 and 2008, USAID funding enabled CDD-Ghana to run a number of programmes aimed at building the capacity of selected parliamentary committees. The targeted committees included the Constitutional, Legal and Parliamentary Affairs, Subsidiary Legislation, Government Assurances, Judiciary, Local Government, and Social Welfare and State Enterprises Committees. The programmes also offered support towards improving the capacity of the research and public affairs departments of parliament as well as to help mobilize civil society input into parliamentary deliberations and enhance public access to the legislature. Under the same USAID-funded programme, CDD-Ghana also provided technical support to the Judiciary Committee to organize the first-ever nationwide public hearings into perceptions of corruption in the administration of justice in Ghana.

Strengthening the capacity of the oversight and financial management of parliament has attracted by far the most sustained external donor support since the mid-1990s. The Canadian Parliamentary Center (CPC), with funding from CIDA, has maintained a long partnership with the parliament of Ghana. The CPC, the World Bank Institute and CIDA collaborated with the IEA in the mid-1990s to hold workshops and organize exchange visits to relevant institutions in Canada to strengthen the capacity of the public accounts and finance committees of parliament. The CPC programmes have continued in the 2000s under the Accra-based Parliamentary Center (PC), which is also promoting the sharing of experiences among African legislators and legislative institutions. DANIDA has also provided longstanding support to the public accounts committee. CIDA's Ghana Parliamentary Committee Support Project (GPCSP), largely operated through the PC has extended grant support to the five parliamentary committees that oversee the Ghana Poverty Reduction Strategy (GPRS). The GPCSP also create opportunities for civil society dialogue and consultation on the implementation of the GPRS. The project is ultimately aimed at increasing the levels of accountability, transparency, and public participation in the parliamentary process. The GPCSP has so far overseen the training of about a dozen nongovernmental organizations in monitoring poverty reduction projects, held a caucus on the general challenges faced by female members of parliament, and has helped establish links between parliamentary committees and community-based organizations. CIDA highlights the role of the GPCSP in producing outcomes such as increased co-operation and bi-partisan work within selected parliamentary committees, improvement in the capacity and understanding of committee members and their staff, of parliament's role in fostering government accountability, and the advancement of gender equality in the work of key parliamentary committees in Ghana. The World Bank's Public Financial Management

18 Interview with Doe Adjaho, July 2009 (Gyimah-Boadi 2009b). 
Assistance Project (PFMAP), directed at the public accounts, the finance and the poverty reduction select committees, seeks to strengthen the capacity of state institutions to better deliver the public goods necessary to bring about development. The PFMAP has supported the training of research officers and other technical support staff of parliament.

However, some well-meant donor interventions have unwittingly produced deleterious effects on the legislature. The rationale behind donor direct support for the national budget is essentially correct, that is, external assistance to a democratically-elected government must come with little or no 'conditionalities' so that the government would have the opportunity to implement its electoral mandate. Yet, its practical impact is questionable in the political environment of Ghana's Fourth Republic, in which the role of parliament in financial matters is already so severely circumscribed and governments substantially reflect partisan/sectarian interests as opposed to national interests. Budget support in Ghana appears to have further marginalized the role of parliament in budget allocation and control in favour of the finance ministry (Lawson et al. 2007).

\section{External donor contribution to political party development in Ghana}

The progress in party development in Ghana is reflected in the results of parliamentary and presidential contests since 1992. In the 1992 polls, the NDC won 189 of the 200 parliamentary seats; the NDC retained its control of the presidency and parliament (133 seats), but the opposition NPP secured 61 parliamentary seats. 19 The NPP won the presidential vote in 2000, and with 99 seats (and 92 for NDC), overturned the NDC parliamentary majority. The NPP retained its control of both the presidency and Parliament in 2004, but lost them to the NDC in 2008. For all practical purposes, therefore, Ghana is a twoparty state, with the NDC and NPP nearly equal in strength (Whitfield 2009).

However, party development in Ghana still has a long road to travel with respect to important benchmarks. For example, the representation of women in the ranks of party executives or presidential and parliamentary candidates in all the parties is extremely weak. At present, there are only 19 women among the 230 MPs in Ghana, a reduction from 25 women in the previous parliament.

With respect to internal democracy, the record is mixed. On the positive side, the internal affairs of Ghanaian political parties are typically guided by more or less democratic constitutions. They choose their presidential and parliamentary candidates, and constituency, regional and national level executives through fairly democratic elections supervised by the Electoral Commission. Contestants and other party members who believe the process has been breached constitutionally or legally can mount a challenge in the courts. However, the internal decision-making processes are disturbingly oligarchic and popular voice often is drowned out by vested interests within the parties. Party candidates and executives are typically chosen by an electoral college that is unrepresentative of the broad membership of the parties and are susceptible to capture by the party elite. The opposition NPP has broken with tradition in recent years by significantly expanding the size of the body that elects its national executives and presidential candidate from under 3000 to approximately 115,000 members. But the prevailing arrangement in the ruling NDC, in which only about 3,000

19 One seat remained vacant due to legal battles over the eligibility of candidates. The NPP later won it in a byelection held in June 1997. 
delegates elect the national executives and presidential candidate, is more typical. Ghanaian parties are also highly centralized with power concentrated in the hands of national executives. For instance, party policy platforms are crafted by a selected few with little input from the grassroots. Thus, while the pretence remains, decisions made within the party are hardly democratic.

Furthermore, the existing arrangements for party financing are also highly opaque and inequitable. In theory, the parties are expected to secure their funding largely through contributions of approximately US $\$ 150$ from each member of the rank and file, the sale of party cards and paraphernalia, and other fund-raising events. Presidential and parliamentary candidates are also asked to make contributions to their respective parties, especially in the form of expensive registration/filing fees during the party primaries. 20 But, in practice, contributions from undisclosed private business interests or individuals appear to be the main sources of direct funding. Moreover, trends in party financing since 1992 indicate a decline in the proportion of internally generated party revenue (Saffu 2003; Kumado 1996; GyimahBoadi and Debrah 2008). It is therefore not surprising that Ghanaian political parties generally suffer from chronic shortage of funding, especially as elections in the Fourth Republic have become increasingly competitive and evidently expensive.

Worse still, the sources of funding for both government and opposition parties are hardly transparent and possibly illicit in some instances. Although the law requires all parties to annually submit their financial transactions to the EC for scrutiny within six months every year, 21 the parties rarely fulfil this obligation. They erroneously and self-servingly interpret their de facto self-financing status to mean that parties are not obliged to fully disclose their financial transactions. These prevailing financing practices most severely disadvantage opposition parties. Once they come into government, ruling parties and candidates invariably and somewhat 'magically' become better funded and resourced than their opposition counterparts. Simultaneously, the former ruling party joins the chorus of resource-starved opposition parties.

Incumbency confers unfair and nearly unfettered advantages. Incumbent governments routinely abuse the state tender processes to generate kickbacks for election purposes. In addition, access to state-controlled resources enables the governing party to reward party workers in the form of employment in state institutions. Individuals and private companies enthusiastically donate to the ruling party in expectation of presidential appointments and public works contracts, (see Debrah 2005; Sandbrook and Oelbaum 1999: 42-4). Tellingly, nearly all ruling party national and local executives become businessmen and contractors.

Incumbents also enjoy another kind of advantage: they are able to engage in profligate election-year expenditures (aided sometimes by external economic and social development assistance, which serves as 'strategic rents'), and this can tip a close election in their favour. Incumbency also enables the government/ruling party to directly deploy state institutions such as the Ghana Broadcasting Corporation and Ministry of Information in partisan political campaigns, though a Supreme Court decision in July 1993 has somewhat abated the latter inequity.

20 In the 1992 polls, the state provided limited in-kind funding, campaign vehicles and free broadcasting space on the state-owned electronic media, but there is no indication that the practice has continued since.

21 Republic of Ghana, 1992; Act 574. 
External donors have tried, but not necessarily succeeded, in helping to reduce some of the above gaps in political party development. They have facilitated the development of a vibrant party system by helping to level progressively the playing field for elections. Competitive elections have in turn increased the motivation of political parties to organize their structures and mobilize voters. Donor interventions promoting free speech, equal access to state media and balanced political reporting, among others, have similarly aided the efforts of parties, particularly the opposition, to establish a national presence and canvass for votes.

Some donor interventions have been more directly targeted at party development. The German Political Party Foundations (FES, KAF, FNF) have provided leadership training and other technical support to political parties. Perhaps the most direct external support for party development has come through the Dutch government-sponsored Ghana Political Parties Programme (GPPP) implemented collaboratively by the Dutch NGO, IMD and the IEA. The programme, which provides regular grant support and technical assistance to political parties with representation in parliament, helps to strengthen the institutional capacity of the parties and partially levels the electoral playing field for minority parties. Its impact on the hugely under-resourced opposition parties, the Convention People's Party and the People's National Convention appears to be even greater: it has helped them to stay alive, to keep a modest presence in parliament, and to present the possibility for a 'third party' option to break the electoral tie between the two main parties, NDC and NPP. Notably, this programme appears to violate existing laws explicitly prohibiting external funding of political parties.22 Nevertheless, the GPPP was a major factor in the ability of the IEA to organize debates among qualifying presidential candidates in the 2008 polls. These debates were particularly successful in fostering at least a temporary degree of inter-party amity during the otherwise highly acrimonious electoral contest. Forums organized under the programme also facilitated the development of a voluntary code of conduct to guide the behaviour of the parties and candidates during the campaign, though individual politician and party's compliance with the code is often trumped by their calculation of the partisan advantages they derive from specific violations.

\section{External support to the media and civil society}

The media and civil society have been key actors in Ghana's democratic governance process, as indicated in the foregone analysis. Private media sources, in particular, were instrumental in Ghana's two peaceful electoral turnovers. In the last three elections, FM radio stations across the country consistently provided political news and, through live phone-in programmes, allowed direct public access to candidates and their platforms. Private FM radio stations have also contributed to the promotion of peace during elections by highlighting potential flashpoints during polls and have independently collated poll results. Consequently, the Ghanaian media has become the most important bulwark against election fraud.

Thanks to the media, overseas development assistance (ODA) to Ghana, which represents an average of about 30 per cent of the annual budget, as well as other activities are wellpublicized. Parliamentary debates on the budget as well as various agreements with Ghana's development partners routinely make it into the news and become fodder for many political

22 Article 55 (15) of the Constitution notes that: 'Only a citizen of Ghana may make a contribution or donation to a political party registered in Ghana'. 
talk shows. Increased media scrutiny over government transactions, such as the use of the HIPC facility by the Kufuor administration, has aroused the interest of citizens to monitor government programmes and question them. Consequently, the government has become more responsive to citizen concerns. Since 2001, it has become commonplace to hear government ministers and spokespersons on the radio responding to policy questions or allegations of wrongdoing. This is especially important because many communities have no direct contact with central government.

However, the media has significant shortcomings. Its level of professionalism remains low, despite the technical assistance proffered by donors and others. Its reporting and analytical skills as well as its ability to verify facts and evaluate the self-serving claims of politicians and public officials are generally weak. The limited attention paid to particular subjects and the tendency for media coverage to move from issue to issue-even as that particular issue remains significantly unresolved-also undermines the media's ability to hold public officials accountable. Ghanaian journalism, in general, is chronically reactive and event-driven; and donor and other development initiatives that have no immediate political import do not become major news. Journalists hardly undertake any follow-up to implementation and delivery of tangible outputs and benefits from public works and external donor assistance. They are usually present to report dutifully on contract signing, ribbon-cutting, and inauguration ceremonies of some completed development projects, but almost never inbetween. This allows the media agenda to be mainly set by the government propaganda machinery and opposition political parties. In addition, some sections of the media allow themselves to be co-opted by the government, especially national security agencies, political parties and other partisan political interests as well as individual politicians, which undermines the overall credibility of the sector.

The lingering culture of suspicion of, and hostility to, media among many Ghanaian officials, particularly government and ruling party officials, has been a greater obstacle to the realization of the promise of a liberalized media in Ghana enshrined in the 1992 Constitution.23 It blocked the progress of media liberalization in the first eight years of democratic rule as the Rawlings/NDC government resurrected and heavily applied laws on media repression inherited from Ghana's authoritarian past (and yet to be reconciled with the constitution), notably the criminal libel and sedition laws, to harass and intimidate the nascent private media. It also used the security services to arrest journalists on the slightest provocation and with little recourse to the law. Similarly, under the Mills-NDC administration, a number of journalists have been arrested under the controversial Section 208 of the Criminal Code. This Code states that 'any person who publishes or reproduces any statement, rumour or report which is likely to cause fear and alarm to the public or disturb the public peace, knowing or having reason to believe that the statement, rumour or report is false is guilty of a misdemeanour'.24 The entrenched culture of official secrecy also severely

23 See Article 162 of the Constitution of Ghana. Article 162(3) forbids the requirement of a license for the establishment or operation of private press/media in Ghana. It also entrusts the responsibility of promoting press freedom and insulating the state-owned media from governmental control to an independent media regulatory body (National Media Commission (NMC). A series of court decisions also ensured that the statecontrolled broadcaster offers equal access to both government and opposition viewpoints, in keeping with the requirements of Article 163 of the Constitution.

24 This, for instance, provided the legal cover for the arrest in July 2010 of the news editor of an Accra FM radio station who reported that members of a local real estate developers association had received death threats for their public statements opposing the government's proposed multi-billion dollar contract with a South Korean company for the construction of residential houses in Ghana. His refusal to reveal the source of the information to the police caused him to be charged with the offence of 'publishing false news' under 
undermines the Ghanaian media's effectiveness. It is worth noting that donor-supported civil society and media advocacy for the enactment of a credible right to information legislation in the Fourth Republic has stalled under three presidents.

External donors played a significant role in the realization of some of the core free speech ideals envisaged under the new democratic constitution and the emergence of a free media and civil society in Ghana today. Western donors and embassies were highly active in the local crusades against the persistent culture of official repression of the media, in spite of the new democratic dispensation under the Rawlings-NDC government. A senior US diplomat was deported from Ghana in 1997 for his part in this crusade and others were threatened for the same reason. The crusade inspired the newly installed Kufuor-NPP administration to repeal the Criminal Libel and Seditious Laws of the Criminal Code in 2001, in accordance with its election campaign promise. The relaxation of official restrictions on the media and free expression has significantly contributed to the tremendous progress the country has made in media liberalization since the early 1990s. In contrast to the state's near monopoly over the electronic media up until the mid-1990s and its almost exclusive control over the print media up to the late 1980s, the country today has 136 newspapers, 50 television stations (including satellite TV) and 146 FM radio stations, including BBC, VOA and other international media organizations. External donors deserve some of the credit for Ghana's achievement as one of the freest and the most unfettered in Africa, surpassing even France, Spain and Italy, on the Freedom House 2009 survey ranking.

External donor assistance has been equally crucial for the development of the technical capacity of the media. DANIDA, USAID, and in particular, the Friedrich Ebert Stiftung (FES) have been leading external actors on this front. They, together with the Dutch and US embassies, as well as the British High Commission, have regularly sponsored journalists to attend professional training programmes organized locally or abroad. The FES has, however, been the most important media development partner in Ghana. It has organized training for journalists on subjects ranging from electoral reporting to financial and economic journalism and committed substantial resources to fund various media development publications. The National Media Commission (NMC), for instance, has largely depended on FES support for its training programmes for journalists. DANIDA has also supported training for journalists in ethics and professional development and USAID has collaborated with Yankah and Associates to train journalists on HIV/AIDS reporting. Other agencies that have supported the training of Ghanaian journalists include Journalists for Human Rights (JHR) (in human rights reporting) and the Center for Media Analysis (in online journalism). The German Gesellschaft für Zusammenarbeit (GIZ) and UNESCO have also supported the establishment and development of community radio stations in Ghana. Other foreign media organizations like the BBC and Deutche Welle have also supported media development. At the very least, external support has helped to strengthen Ghana's media by filling some of the gaps in professional training and financing that the private market and the state do not provide.

The earlier discussions have already captured the deep and often creative engagement of domestic civil society with Ghana’s good governance and democratic development projects in

Section 208 of the Criminal Code. Another reporter was arrested and charged under the same section of the criminal code for an innocuous story in a state newspaper claiming that uncompleted buildings and unused lands meant to house police personnel in a provincial capital had been abandoned and were now being occupied by squatters and possibly criminal elements. Curiously, these developments elicited no reaction from Ghana’s external donors. 
areas such as election credibility promotion and parliamentary strengthening. They have mounted campaigns in favour of official transparency, anti-corruption, gender equity and human rights, in addition to economic and social development. The Center for Policy Analysis (CEPA), IEA, the Private Enterprises Foundation and the libertarian think-tank, IMANI-Ghana, for instance have been in the forefront of economic policy advocacy. CEPA, for instance, publishes the Ghana Economic Review and Outlook, which provides in-depth analysis of the country's public finance and fiscal issues, and the Ghana Selected Economic Series, which identifies emerging economic issues. IMANI-Ghana has provided useful market-based critiques of economic and social policymaking. The work of civil society organizations like Women in Law and Development (WILDAF), International Federation of Women Lawyers (FIDA) and Ghana Federation of the Disabled helped to achieve improvements with respect to the rights of women and other minority groups. Indeed, the Domestic Violence Law would probably not have come into existence without the trenchant advocacy of the WILDAF, Abantu, FIDA and other gender focal NGOs. Likewise, the passage of the Disability Act was largely due to the advocacy of CDD-Ghana, supported by funding from USAID. The Ghana Integrity Initiative, the local chapter of Transparency International, has been at the forefront of anti-corruption advocacy in the country. Their work is complemented by other civil society organizations such as CDD-Ghana, IDEG, and the Commonwealth Human Rights Initiative (CHRI). CHRI has been leading the campaign to pass a Freedom of Information law for Ghana, which should help advance the struggle for greater government transparency.

A number of factors, however, impair the overall effectiveness of Ghanaian civil society. They include the following: weak research and analytical capacity, which is reflected in the paucity of independent public expenditure tracking and other evidence-based advocacy; overconcentration of prominent and technically strong NGOs in urban rather than rural areas; weak and insecure funding base and dependence on external donor funding, which undermines sustainability and the NGOs' nationalist credentials; the presence of rogue actors in the sector that reflects the absence of a credible code of conduct/weak self-regulation by sector operators and which renders the sector susceptible to predatory government attacks; a tendency to avoid taking positions unpopular with government and the ruling party and to give undue deference to the state, which enables the government to cherry pick civil society bodies for inclusion in national policy decisions, regardless of merit, and ostracise those it deems 'unfriendly'; and inadequate championing of the interests of key productive sectors such as cocoa farmers, fishermen and private sector. In addition, there has been weak attention to the rights of sexual and other social minorities, reflected in the failure to counter official and individual attacks on the rights of sexual minorities. For instance, interior minister Kwamena Bartels banned a peaceful assembly of gays and lesbians in May 2007 on the grounds that homosexuality is illegal in Ghana. Moreover, police were unresponsive when a vigilante group raided a private birthday party in Accra, which they claimed involved gays and lesbians. Regrettably, external donors have not publicly spoken up against these rights' infringements.

Nevertheless, in the absence of a local private and philanthropic funding sector, external funding and technical assistance have been crucial to the ability of Ghanaian civil society to successfully implement its various democracy promotion initiatives. Bilateral donor funding directly channelled to individual NGOs and/or through pooled/basket fund arrangements (such the erstwhile Ghana Research and Advocacy Program and the current Star-Ghana) has provided a lifeline to Ghanaian civil society. In some cases, it is external donor insistence, or at least prompting, that secured representation for domestic civil society and non-state actors 
in Ghana's normally state/executive branch dominated policy-making and evaluation forums and process.

\section{$7 \quad$ Lessons and conclusions}

As a form of soft power, external assistance has impacted significantly on Ghanaian democratization. The decision by the quasi-military Rawlings administration to transition to multi-party democracy was at least indirectly influenced by the push of the World Bank/IMF/western donors for client nations like Ghana to open up their political systems in the early 1990s. External aid in general, and democracy and governance aid in particular, have played a significant role in helping to keep it on track. Democracy support was particularly effective in saving the Ghanaian democracy project from an infantile death and, along with development aid, has broadly helped to keep it on track. Sustained external democracy support has been particularly helpful in making the machinery for election administration relatively efficient and the electoral process generally transparent, peaceful and credible. It has also helped to promote human rights, media freedoms and civil society participation in the democratic and governance process in the Fourth Republic. Although not explicitly targeted at promoting democracy, the timing of external assistance packages such as HIPC relief and the MCC grant suggests recognition of Ghana's democratic gains and subtle encouragement to stay on course. Both the HIPC and MCC grants coincided with Ghana's first electoral turnover and the official embrace of the African Peer Review Mechanism governance self-assessment. The HIPC Initiative, for example, dominated public discussion so much so that the acronym 'HIPC' became synonymous with 'being broke' in Ghanaian popular culture. Nonetheless, external aid has proved less effective in helping to move Ghana beyond electoral democracy to 'liberal democracy' (Diamond and Morlino 2005) and to improve the quality of governance. Thus, gaps continue to exist in governmental transparency, accountability and responsiveness, and adherence to the rule of law (Diamond 1999).

A few lessons can be deduced from Ghana's experience with external democracy assistance since the early 1990s. First, the domestic environment, including commitment by the political elite to reforms and co-operation with donors, matters a great deal. In general, external assistance succeeded in pushing democratic reforms in Ghana when the commitment of political elites, especially those in the incumbent regime, has been strong. Rawlings and the PNDC government demonstrated considerable commitment by agreeing to embark on a democratic transition despite the real risk of losing power. The elected Rawlings-NDC administration also showed commitment to making the democratic transition work by allowing reforms to the electoral system that rendered subsequent polls more competitive, reduced the certainty of electoral victory, and ultimately handed power over to the opposition NPP in 2000. Similarly, the NPP sought to control revenge impulses after assuming office in January 2001 by setting up a non-retributive South African-style truth commission to deal with past abuse of state power and human rights violations under previous administrations. In 2008, the NPP also conceded defeat to the NDC in the presidential elections despite the narrowness of its defeat. By contrast, strong external donor support and continued push by civil society and media for the passage of Right-to-Information legislation and reform of the Public Officeholder Asset Disclosure regime have proved futile in the face of the reluctance of the bipartisan political elite to impose such discipline on their own power. 
Second, demand of the domestic opposition and civil society for external democracy assistance is crucial to the effectiveness of the external support proffered. The domestic opposition's insistence on substantial improvements in election transparency and fairness as the prerequisite for their participation in the 1996 election, supported by most of the media and civil society, created the right environment for extensive donor involvement in the mid1990s' reforms. Third, external assistance appears to have a better chance of achieving a significant impact when sustained over a relatively long period, as in the case of support to elections.

Fourth, there are limits to the influence of external aid on democracy and governance reforms. Indeed, regardless of the levels of donor support, shortcomings in election administration and electoral credibility, it is difficult to see how political competition in Ghana's Fourth Republic would be less fraught, and 'state capture' not the sole motivation for political elites when constitutional arrangements and political conventions over-concentrate power in the hands of the central government and president. Some desired changes and improvements in the quality of democracy and good governance simply lie beyond the control of foreign aid. The disempowering provisions in the 1992 Constitution with respect to the legislature and the internal rules of the institution itself, such as the power wielded by a president-appointed speaker, severely limit the impact that external donor support to strengthening the parliamentary process and other similarly targeted programmes can have on parliamentary effectiveness. A number of changes affirmative to democracy and good governance in general and constitutionalism in particular have been proposed to the presidential commission that reviewed the 1992 Constitution in 2010/11 (Gyimah-Boadi 2010b; Abotsi 2010; Prempeh 2010, 2011). But it is too optimistic to expect that the presidency and executive branch would readily and without a fight concede to amendments that essentially reduce their powers.

In addition to these longstanding challenges, a number of new considerations question the continuing role and importance of the donor community in promoting democracy in Ghana. One important factor is Ghana's growing natural resource wealth, notably oil from which the annual government revenue in the next twenty years would roughly equal the annual development assistance that the nation currently receives. This is likely to alter the nature of Ghana's relations with its developed country partners, potentially reducing their influence and their ability to promote reforms deemed unpalatable or even inexpedient from the standpoint of domestic politics. Indeed, the country's emerging oil and gas resources have attracted China, India and other non-traditional development and trading partners. Their presence provides the government with the leverage to resist external pressure for reform. It also appears to be driving Ghana's traditional development partners to recalibrate their own established governance benchmarks in their bid to retain access to the state and incumbent administrations.

Moreover, in the wake of the recent global financial crisis, Ghana's traditional development partners have become preoccupied with addressing their own domestic and regional economic and social problems. This, in turn, is putting under strain their commitment to the liberal democratic principles that have underpinned post-Cold War development co-operation. The crisis has increased the possibility that Ghana's traditional bilateral donors are less capable of providing leadership to non-traditional donors on issues of democracy, good governance and human rights. This presents the threat of a return to the Cold War era when development assistance was strongly guided by geopolitical considerations. It is therefore likely that the future of Ghanaian democratic development will depend increasingly on domestic factors and forces, and less on external assistance particularly from the advanced democracies. 


\section{Acronyms}

\begin{tabular}{|c|c|c|}
\hline APRM & - & African Peer Review Mechanism \\
\hline CDD & - & Center for Democratic Development \\
\hline CEPA & - & Center for Policy Analysis \\
\hline CHRAJ & - & Commission on Human Rights and Administrative Justice \\
\hline CHRI & - & Commonwealth Human Rights Initiative \\
\hline CIDA & - & Canadian International Development Agency \\
\hline CODEO & - & Coalition of Domestic Election Observers \\
\hline DANIDA & - & Danish International Development Agency \\
\hline DFID & - & Department for International Development (of the UK) \\
\hline EU & - & European Union \\
\hline FAO & - & Food \& Agriculture Organisation \\
\hline FES & - & Friedrich Ebert Stiftung \\
\hline FIDA & - & International Federation of Women Lawyers \\
\hline GDP & - & Gross Domestic Product \\
\hline GJA & - & Ghana Journalists’ Association \\
\hline GPCSP & - & Ghana Parliamentary Committee Support Project \\
\hline GPPP & - & Ghana Political Parties Programme \\
\hline GPRS & - & Ghana Poverty Reduction Strategy \\
\hline HIPC & - & Highly Indebted Poor Countries Initiative \\
\hline HIV & - & Human Immuno-defiency Virus \\
\hline IDEG & - & Institute for Democratic Governance \\
\hline IEA & - & Institute of Economic Affairs \\
\hline IFAD & - & International Fund for Agricultural Development \\
\hline IIAG & - & Ibrahim Index of African Governance \\
\hline ILO & - & International Labor Organisation \\
\hline IMD & - & Netherlands Institute for Multiparty Democracy \\
\hline IMF & - & International Monetary Fund \\
\hline IOM & - & International Organisation on Migration \\
\hline IPA & - & Institute for Policy Analysis \\
\hline IPAC & - & Inter-Party Advisory Committee \\
\hline MCC & - & Millennium Challenge Corporation \\
\hline MDBS & - & Multi-Donor Budget Support \\
\hline MDRI & - & Multilateral Debt Relief Initiative \\
\hline MOFEP & - & Ministry of Finance and Economic Planning \\
\hline
\end{tabular}




$\begin{array}{lll}\text { MP } & - & \text { Member of Parliament } \\ \text { NDC } & - & \text { National Democratic Congress } \\ \text { NDI } & - & \text { National Democratic Institute for International Affairs (of the USA) } \\ \text { NMC } & - & \text { National Media Commission } \\ \text { NEDEO } & - & \text { Network for Domestic Election Observers } \\ \text { NEPAD } & - & \text { New Partnership for African Development } \\ \text { NPP } & - & \text { New Patriotic Party } \\ \text { ODA } & - & \text { Overseas Development Assistance } \\ \text { OPEC } & - & \text { Organization of the Petroleum Exporting Countries } \\ \text { PFMAP } & - & \text { World Bank's Public Financial Management Assistance Project } \\ \text { PNDC } & - & \text { Provisional National Defence Council } \\ \text { RWI } & - & \text { Revenue Watch Institute } \\ \text { SBS } & - & \text { Sector Budget Support } \\ \text { SWAp } & - & \text { Sector Wide Approach } \\ \text { UK } & - & \text { United Kingdom } \\ \text { UNAIDS } & - & \text { Joint United Nations Programme on HIV/AIDS } \\ \text { UNDP } & - & \text { United Nations Development Programme } \\ \text { UNESCO } & - & \text { United Nations Educational, Scientific and Cultural Organisation } \\ \text { UNFPA } & - & \text { United Nations Population Fund } \\ \text { UNICEF } & - & \text { United Nations Children's Fund } \\ \text { UNIDO } & - & \text { United Nations Industrial Development Organization } \\ \text { UNU } & - & \text { United Nations University } \\ \text { USA } & - & \text { United States of America } \\ \text { USAID } & - & \text { United States Agency for International Development } \\ \text { WFP } & - & \text { World Food Programme } \\ \text { WHO } & - & \text { World Health Organization } \\ \text { UNA } & & \end{array}$




\section{References}

Abotsi, E.K. (2010). 'Strengthening the Liberal Roots of the 1992 Constitution: An Agenda for Reform’. Constitutional Review Series, 2. Accra: CDD-Ghana.

Afrobarometer: '2008 Summary of Results': Round 4 Survey in Ghana. Available at http://www.afrobarometer.org/index.php?option=com_content\&view=category\&layout=bl og\&id=11\&Itemid=16

APRM (African Peer Review Mechanism) (2005). 'Country Review Report of the Republic of Ghana, June 2005'. Available at: /www.afdb.org/fileadmin/uploads/afdb/Documents/Project-and-Operations ～/00798283EN-APRM-GHANA-REVIEW-REPORT-JUNE-2005.PDF. Accessed 12 March 2012.

CDD (Ghana Center for Democratic Development) (1999). 'Balanced Political Reporting and Democratic Development in Ghana: Proceedings of Workshop for Media Practitioners'. Accra: CDD.

CDD (2001). 'Monitoring Media Coverage of the 2000 Elections'. Accra: CDD //could also be Media Coverage of the 2000 Elections (No. 8).

Debrah, E. (2005). 'The Electoral Process and the 2000 General Elections in Ghana'. In T. Lumumba-Kasongo (ed.), Liberal Democracy and its Critics in Africa: Political Dysfunction and the Struggle for Social Progress. New York \& Pretoria: CODESRIA, 125-48.

Diamond, L. (1999). Developing Democracy: Toward Consolidation. Baltimore: The Johns Hopkins University Press, 64-116.

Diamond, L., and L. Morlino (2005). Assessing the Quality of Democracy. Baltimore: The Johns Hopkins University Press, chapters 1-5.

GoG (Government of Ghana) (2010). 2008 Ghana Millennium Development Goals Report. Accra: National Development Planning Commission (NDPC)/Government of Ghana and the United Nations Development Programme (UNDP) Ghana. Available at: www.undpgha.org/site/docs/GhanaGhanaMDGReport-2010.pdf

Gary, I. (2009). 'Ghana's Big Test: Oil’s Challenge to Democratic Development'. Washington, DC: ISODEC-OXFAM America. Available at: www.oxfamamerica.org/files/ghanas-big-test.pdf.

Gyimah-Boadi, E. (1997). 'Ghana's Encouraging Elections: The Challenges Ahead'. Journal of Democracy, 8(2): 78-91.

Gyimah-Boadi, E. (2009a). ‘Another Step Forward for Ghana’. Journal of Democracy, 20(2): 138-52.

Gyimah-Boadi, E. (2009b). 'Assessing Democracy Assistance: Ghana'. Madrid: FRIDE. Available at: www.fride.org/publication/784/ghana.

Gyimah-Boadi, E. (2010a). Countries at the Crossroads 2010: Country Report: Ghana. Freedom House Report online. Available at: www.freedomhouse.org/report/countriescrossroads-2010/ghana. 
Gyimah-Boadi, E. (2010b). 'Towards a Constitution for Democratic and Well-Governed Ghana'. Constitutional Review Series, 1. Accra: CDD-Ghana.

Gyimah-Boadi, E., and E. Debrah (2008). 'Political Parties and Party Politics'. In B. Agyeman-duah (ed.), Ghana Governance in the Fourth Republic. Accra: CDD-Ghana, 126-54.

Freedom House (2011). Freedom in the World, Ghana Country Report, at http://www.freedomhouse.org/report/freedom-press/2011/ghana. Retrieved on 1 April 2012.

Freedom House (2009). Freedom of the Press, Ghana Country Report, at http://www.freedomhouse.org/report/freedom-press/2009/ghana. Retrieved on 1 April 2012.

Kumado, K. (1996). Financing Political Parties in Ghana: The Case for Public Funding'. In K. Kumado (ed.), Funding Political Parties in West Africa. Accra: Friedrich Ebert Foundation.

Lawson, A., G. Boadi, A. Ghartey, A. Ghartey, T. Killick, Z.K. Agha, and T. Williamson (2007). Joint Evaluation of Multi-Donor Support to Ghana. London: ODI and Accra: CDD-Ghana. Available at: www.odi.org.uk/resources/download/204.pdf

Mo Ibrahim Foundation (2011). Press Release, 10 October London: Mo Ibrahim Foundation. Available at: http://www.moibrahimfoundation.org/en/media/get/ 20111005_Ghana.pdf. Accessed 12 March 2012.

MOFEP (Ministry of Finance and Economic Planning) (2010). 'Performance Assessment Framework of Development Partners (DP-PAF) in Ghana: Baseline Report 2009. Available at: www.gersterconsulting .ch/docs/baseline\%20report\%20dp-paf\%20final.pdf.

MOFEP (Ministry of Finance and Economic Planning) (2012). MOFEP Report 'Inflation Rate Ticks up to 8.7 Per Cent in January'. Available at: www.mofep. gov.gh/?q=news/160212. Accessed 12 March 2012.

NPP (New Patriotic Party) (1992). The Stolen Verdict: Ghana, November 1992 Presidential Election Report of the New Patriotic Party. Accra: NPP.

O’Donnell, G. (1996). 'Illusions about Consolidation'. Journal of Democracy, 7(2): 34-51.

Pereira, S. (2000). 'Ghana: Economic Development in a Democratic Environment'. IMF Occasional Paper 199. Washington, DC: IMF.

Prempeh, H.K. (2010). 'Reforming the Constitution of Ghana for a New Era: Averting the Peril of a Constitution without Constitutionalism'. Constitutional Review Series 3. Accra: CDD-Ghana.

Prempeh, H.K. (2011). 'The 1992 Constitution and Public Financial Management: Challenges and Opportunities for Reform’. Constitutional Review Series, 4. Accra: CDD-Ghana.

Quartey, P., C. Ackah, G. Dufe, and E. Agyare-Boakye (2010). 'Evaluation of the Implementation of the Paris Declaration on Aid Effectiveness: Phase II'. Final Country Report for Ghana. Available at: www.oecd.org/dataoecd /61/29/47083187.pdf

Ramos-Mrosovsky, C. (2012). 'Can Ghana Escape the "Oil Curse”'. Africa Law Today, 4(1): $1-4$. 
RWI (Revenue Watch Institute) (2011). 'Managing Oil Revenues in Ghana: Review of Early Revenue and Expenditure Trends’. Accra: RWI.

Saffu, Y. (2003). 'The Funding of Political Parties and Election Campaigns in Africa'. In R. Austin and M. Tjernstrom (eds), Funding of Political Parties and Election Campaigns. Sweden: IDEA Handbook Series.

Sandbrook, R., and J. Oelbaum (1999). 'Reforming the Political Kingdom: Governance and Development in Ghana’s Fourth Republic'. CDD Critical Perspective 2. Accra: CDDGhana.

Tsekpo, A., and A. Hudson (2009). Parliamentary Strengthening and the Paris Principles: Ghana Case Study. Overseas Development Institute (ODI), January. Available at: http://www.odi.org.uk/resources/docs/4401.pdf

Whitfield, L. (2009). 'Change for a Better Ghana: Party Competition, Institutionalization and Alternation in Ghana’s 2008 Elections’. Journal of African Affairs, 108: 621-41.

World Bank (n.d.). 'Governance Reports: Country Data Report for Ghana, 1996-2010'. Washington, DC: World Bank. Available at: www.info.worldbank.org/governance/wgi/pdf/c82.pdf. Accessed on 12 March 2012. 